\title{
A TRIBE CALLED TEXT: WHITMAN AND REPRESENTING THE AMERICAN INDIAN BODY ${ }^{1}$
}

\author{
Nicholas Soodik
}

IN THE 1855 EDITION of Leaves of Grass, the poet asks: "The friendly and flowing savage. . . Who is he? / Is he waiting for civilization or past it and mastering it?"2 Though seemingly rhetorical, the question begs for an investigation about the nature of the "savage" figure in Walt Whitman's work. A line two pages earlier provides a clue: "the savage at the stump, his eye-sockets empty, his mouth spirting whoops and defiance" (58). Yet, it is Whitman himself who often sounds confounded or "stumped" by the savage. The poet's eye-sockets appear empty, unable to make an imaginative space for the Indian in his lines. "They have left me helpless to a red marauder," Whitman writes, perhaps calling a helpless "whoop" of his own while working to envision and define the Native. $^{3}$

The Indian figure thus registers a note of dissonance for a poet who seeks to charge his text, as contemporary critics urge, with an embracing corporeal presence. Karen Sánchez-Eppler traces Whitman's project of "poetic embodiment . . . [which] permits his multiple migratory 'I' to inhabit the body of the other in all its difference." In similar fashion, Michael Moon finds a "generative contradiction" in Whitman's bodily poetics, "that which exists between Whitman's repeated assertions that he provides loving physical presence in the text and his awareness of the frustrating but ultimately incontrovertible conditions of writing and embodiment that actually render it impossible for him to produce in his writing more than metonymic substitutions for such contact." ${ }^{5}$ For Moon, Whitman's project turns on the epistemic site of the body, as the poet struggles with the indefatigable desire to physically handle the readers and characters of his text.

This essay seeks to refine such scholarly efforts by examining the language with which Whitman represents the American Indian body. If we attach the issue of corporeality in Whitman's writing to the poet's wish to transgress the medium of writing, "to project actual physical presence in a literary text," then the image of the Indian, I will argue, locates the endeavor's inevitable site of failure. Instead of working to embody the character of the Indian, Whitman textualizes and, conse- 
quently, obscures the Indian body, aligning the indigenous American with the trope of writing and the composition of the text itself. That Whitman neglects to corporealize the Indian body reminds us that the national body the poet celebrates is mobilized precisely by his literary construction, rather than a pre-existing nineteenth-century social reality. So, where Ed Folsom writes that Whitman's Indian figure indicates a "tortured ambivalence about the role America's natives would play in the development of the country's character," I suggest that the Indian in Whitman's texts emblematizes the ambivalence of the nation's figuration. ${ }^{6}$

Writing in the 1855 preface to Leaves, "the United States themselves are the greatest poem," Whitman makes clear his wish to poeticize the American narrative and its characters. The responsibility of the American poet, according to Whitman, is not only to evoke but also to embody the spirit of the nation: "a bard is to be commensurate with a people. . . . His spirit responds to his country's spirit. . . . he incarnates its geography and natural life and rivers and lakes."7 Whitman's figuration of the country and the national poet is redirected inwardly here, moving from a topographical account of the land to physiognomic metaphors which emphasize interior elements of the poet's anatomy: "Of all nations the United States with veins full of poetical stuff most need poets ... [the poet] can make every word he speaks draw blood," Whitman writes. "He offers the sweet firmfibred meat that grows men and women. His brain is the ultimate brain" (713).

By thus establishing the symbolic coordinates of the nation through the poet's body - or, to put it differently, (mis)recognizing the poet's body as an imaginary reflection of the nation-Whitman's poetic persona implicitly expresses the desire for a cohesive and uniform sense of "Americanness." As a marker of aboriginal America, the Indian figure authorizes Whitman's poetic patriotism; yet as a testament to the very disunity the poet wishes to whitewash, the figure frustrates Whitman's literary project. Whitman's failure to imagine a corporeal Native presence thus recalls what Cherokee artist and critic Jimmie Durham designates the central national myth: "America's narrative about itself centers upon, has its operational center in, a hidden text concerning its relationship with American Indians. That central text must be hidden, sublimated, and acted out." ent the stakes of Whitman's venture. Rather than seeking to "meld . . . into a complete undifferentiated oneness" with the indigenous body, as Sánchez-Eppler finds, I contend, then, that Whitman acts to re-press the Indian into the text, to obtain the fixity and identity of the symbolic order. ${ }^{9}$ The textual act of re-pression, by which I intend to denote a simultaneous act of expression and repression, helps to designate the ambivalence in the poet's device for representing and writing over an aboriginal presence. 
To illustrate my claims, I will focus on a variety of Whitman texts in which the Indian seems present, reading his more famous "Song of Myself" and "Starting from Paumonok," yet spending equal time with a lesser known observation from his 1865 journal, as well as a frequently ignored prose piece, "The Half-Breed." I will close by reading "The Sleepers," a poem included in the 1855 edition yet under-read by critics and Whitman scholars. The poem provides a refreshing image of an Indian woman interacting dialogically with the poet's mother, and works to reveal the fantasy of national unity on which Whitman's political project depends.

\section{(Un)Dressing the Indian Figure}

The textualization of the Indian figure, I argue, results in the failure of embodiment and circumscribes the sense of corporeality in Whitman's texts. I see Whitman's investment in the Native, then, as just that: in vestment, clothing, names, the surfaces and semantics of the indigenous. An explicit example from Whitman's journal during his time at the Bureau of Indian Affairs in 1865 helps to focus this analysis and deserves extended quotation:

The Sioux Chiefs, and their party, from far Dakotah, [are] now temporarily in Washington. . . . Any first-class artist or sculptor would never tire of their powerful and massive forms, the gnarly and luxuriant amplitude of their limbs and chests, and the antique and homely fascination of their physiognomies ... absolutely unapproachable as pronounced aboriginal portraits, with all the eloquence of silent but most vital expression, deep-cut lines, and the great eyes of the superior birds $\&$ animals. ${ }^{10}$

Literally confronted with Indian bodies here, Whitman not only withdraws from the "unapproachable" indigenous party, thwarting a possible position of merger, but also re-draws the Indian group, translating their forms into an essentialized and dehumanizing conception of Indianness. In so doing, Whitman activates what Eric Cheyfitz designates the "poetics of imperialism": a theory of metaphor grounded in the desire of what names itself the "domestic" to dominate what it simultaneously distinguishes as the "foreign."11

Whitman continues in his journal, "the inherent and athletic royalty of the man of the woods and mountains, amid all the general deprivations and squalor of the race, is triumphantly vindicated by these Natural Kings, in shapes that make the types and samples of our civilized manhood, in America and Europe, shriveled and puny in comparison" (NUPM 2:881). The poet redefines the Indian here in terms of Euro-American nobility and hyper-masculinity; yet, at the same time, he establishes a degree of separation from the (re)conceptualized image. The Indian group, in Homi Bhaba's words, "is almost the same, but 
not quite." 12 Metaphors of the Indian trace across a cultural spectrum, "call[ing] to mind the best profiles of Egyptian and Assyrian antiquities, but more splendid even than they, and in some respects ahead even of the Greek" (NUPM 2:881). By figuring the Indian party in Euro-American terms, Whitman ironically comes to regulate their distinction, as if recognition of the Indian group depends on a relation of ambivalent difference.

We can see in Whitman's journal what Gerald Vizenor designates the "simulations of absolute fakes." 13 In order to recognize an Indian body, according to Vizenor, the Native must become the figure constructed by white America. Finding the authentic Indian, then, resembles fabricating the phony, and the "most secure simulations . . . become the real without a referent to an actual tribal remembrance" (MM 8). Like his journal, Whitman's poetry simulates measures of difference, clearly evident in the images of Indian clothing. Perhaps only superficial, the symbolic significance of dress functions importantly in Whitman's writing. The poet often looks to valorize the body by metonymically undressing flesh. In "Song of Myself," Whitman commands, "Undrape . . . . you are not guilty to me, nor stale nor discarded, / I see through the broadcloth and gingham" (LGVar. 9). Similarly, Sánchez-Eppler remarks of the picture that stands in for the poet's name in the 1855 edition, "Whitman's placement of the drawing, as has often been argued, privileges flesh, or at least the image of flesh, over name or word as a pointer to identity" (56). The poetic persona indeed longs to "become undisguised and naked" in his text, stripping away layers of veneer in order to discover, "apart from the pulling and hauling," a sense of corporeal immediacy (LGVar. 2, 5).

In the poem eventually titled, "I Sing the Body Electric," Whitman highlights both the significance of the body and the obfuscating nature of clothing: "The expression of a wellmade man appears not only in his face, / It is in his limbs and joints also [. . .] dress does not hide him, / The strong sweet supple quality he has strikes through the cotton and flannel" (LGVar. 122). As M. Jimmie Killingsworth observes of the poem, "The defilers conceal themselves in clothes, the signs of social roles and the obligations of behavior according to custom. But the body makes its demands in defiance of customs, of clothes." ${ }^{14}$ Whitman seeks to celebrate the beauty of the physiognomy while pushing aside the external differences of dress: "Examine these limbs, red black or white .... they are very cunning in tendon and nerve; / They shall be stript that you may see them" (LGVar. 128-129). At this moment, it seems, Whitman acknowledges the flesh of the Indian, making good on a notion of interior sameness - " "we are all really the same men and brethren .... however different our ... dress and language" - - he would later put down in another journal entry (NUPM 881). 
However, the reference to "red" merely serves to signify Indianness, a semantic mode of engagement that evades incorporation through writing, translation, and metaphor. Both Killingsworth and Sánchez-Eppler make note of Whitman's sexual imagination, articulating the terms of embodiment next to a vision of sexual merger. Yet in Whitman's major poem, "Song of Myself," the poet fails to articulate such an attachment and remains stuck on skin-deep differences in Indian representation. The famous "marriage of the trapper . . . [and] a red girl" emblematizes the attachment to vestment referred to earlier:

Her father and his friends sat near by crosslegged and dumbly smoking .... they had moccasins to their feet and large thick blankets hanging from their shoulders;

On a bank lounged the trapper .... he was dressed mostly in skins .... his luxuriant beard and curls protected his neck,

One hand rested on his rifle .... the other hand held firmly the wrist of the red girl. (LGVar. 11)

This narrative vignette not only alters the fluidity of the verse but also labors to inscribe the Indian with the very codes of identity the poet seems to scorn. While Whitman at once commands the bodily presence of other figures in the poem, the Indian appears covered over by and bound up in symbolic markings.

Furthermore, the conspicuous grip of the trapper-simultaneously "rested on his rifle" and "firmly" clasping the "wrist of the red girl"forms a triangulated model that frustrates the resolution of "irreconcilable opposites" Folsom reads in the scene (72). Standing between the Indian and the gun, the trapper thus reenacts what Vizenor terms "manifest manners":

Manifest Destiny would cause the death of millions of tribal people from massacres, diseases, and the loneliness of reservations. Entire cultures have been terminated in the course of nationalism. These histories are now the simulations of dominance, and the causes of the conditions that have become manifest manners in literature ... the surveillance and domination of the tribes ... Manifest manners are scriptural simulations, the causal narratives of racialism, the denial of tragic wisdom, and the cultural leases of objectivism. $(M M 4,16)$

In so doing, the trapper literally fulfills his ascribed identity, entrapping the Indian girl in a pose that, as Betsy Erkkila notices, not only intimates a sense of the poet's complicity with Indian removal policies but also figures the female Indian as an object of patriarchal exchange. ${ }^{15} \mathrm{~A}$ bounded site of difference energized by an asymmetrical power relation, the scene calls to mind the confinement of indigenous peoples and establishes a metonymic Indian reservation within the poem's vision of the nation.

The return of the female Indian in a characteristic Whitman list a few pages later offers the reader a similar view: "The squaw wrapt in her 
yellow-hemmed cloth is offering moccasins and beadbags for sale" (LGVar. 12). Again, the girl appears "wrapt" or tied-up in a dress of differentiation. At the same time, however, the poet (con)fuses libidinal and commercial economies, veiling the Indian woman in a somewhat erotic fashion that begs the reader to gaze beneath her puzzling offer. The "squaw," that is, seems to serve as the "well-riddled target" announced in the preceding line. Similarly, "as the connoisseur peers along the exhibition-gallery" in the entry that follows, the Indian woman is fetishized as the object perhaps in sight. ${ }^{16}$

The same list also includes an Indian representation that alludes to the possibilities of poetic merger in miscegenation that both SánchezEppler and Folsom find in Whitman's writing: the "half-breed." Although Whitman writes in the list, "The half-breed straps on his light boots to compete in the race," the biracial Indian physique, as we shall see, is far from strapping in an earlier Whitman text (LGVar. 11). While the "race" to which the list here refers is unclear, the half-breed figure of Whitman's earlier writings seems hardly of the human one and, as a result, contests the prospect of merger in miscegenation.

\section{Contesting Merger}

In the mid-1840s, Whitman published "The Half-Breed: A Tale of the Western Frontier," a story in which the position of Indians and the formation of national borders - both geographical and imaginative-play central roles. Whitman figures the Indians in the tale using methods that reappear more subtly in other texts. Thus, despite the minimal critical attention to the story, or perhaps, because of it, "The Half-Breed" serves importantly to negotiate the terms of Whitman's engagement with the representation of the Indian.

The novella is set in Warren, "a place situated on one of the upper branches of the Mississippi" in the West, and located in a temporally liminal space between the past and the present: "Less than seven years previously, the site on which the dwellings of the Warrenites now stood, had been a tangled forest, roamed by the savage in pursuit of game."17 This nostalgic reference to a moment in the recent past works to purge the tale of Native inhabitants yet also anticipates the return of a few remaining Indian figures. It thus comes as no surprise when Arrow-Tip, "one of the finest specimens of the Red People-or rather had the evidence of having once been so," and his brother, Deer, (re)emerge in Warren. Furthermore, the temporal introduction foreshadows the brevity of Arrow-Tip's stay. Whitman's struggle to define Arrow-Tip's return, an awkward combination of passive and past tenses, prefigures the Indian's disappearance. After staging a failed attempt at cultural integration, the story indeed ends in the wrongful execution of Arrow-Tip. 
In some sense, the novella centralizes notions of pairing and bonding that point to the concept of merger Sánchez-Eppler finds in Whitman's writing. Peter Brown's marriage provides a point of organization, and the neat coupling of Arrow-Tip and his brother also suggests twinning. Moreover, the story's parenthetical asides regarding the freedom of the West connote a relational sense that perhaps speaks to an urbanizing East and the possibilities for escape in the text. Philip Deloria writes of mid-nineteenth century (white) America: "The society continued to re-appropriate the interior, aboriginal identity of the Indian. . . . As an artifact vanished forever in the ancient past, however, Indianness was also exterior, far removed from the American society of the present." 18 As Deloria notes, the conception of symbolic Indian identity and Western freedom is fraught with ambivalence-indeed, so is the story. Here, Whitman seems to exalt the western town for its libertarian codes yet remains unable to override the concept of law altogether:

The only law [in the West], in fact, to some of the more remote of these places, is public will, and public feeling - a dangerous state of things in a large and vicious city, but far from being attended with the evils which many people imagine, when exercised in the places we allude to. At all events, it is better to be under this sovereign and self-constituted power, than to have no law at all. (EPF 283)

Just as the town Warren celebrates yet contradicts libertarianism, the various pairs and twosomes in the story point not to a notion of unity but rather to the impossibility of mixture and merger. Arrow-Tip's execution and Brown's disappearance disrupt the novella's coupling. That Whitman insists on the first page, "in the West, all men are comrades," while the story, in fact, stages the instability of Indian-white camaraderie, re-presses the presence of Indians and dilutes the strength of his conviction. As the story closes, the qualities of the town Whitman celebrates as indicative of the West seem transformed, creating a place not unlike the "older cities" of the East. The town's small school becomes an "incorporated academy," and a growth in population necessitates the opening of a "legislative office." The binaries of the story, rather than merging, are thus written over as schisms lurk beneath.

Importantly, the character who seemingly straddles oppositions"he was a half-breed, his mother an Indian squaw, and his father some unknown member of the race of settlers"-actually demonstrates the dangers of merger ( $E P F$ 258). Sánchez-Eppler observes of Whitman's poetry, "in miscegenation, Whitman finds an extremely potent instance of mediation, a blatant demonstration that otherness can be reconciled" (59). However, the figure of the "half-breed," Boddo, works against a unifying conception of miscegenation: "He was deformed in body-his back being mounted with a mighty hunch, and his long neck bent for- 
ward, in a peculiar and disagreeable manner . . . his intellect itself was not very bright" (EPF 258). Disfiguring the title character's form in this manner, Whitman incises the Indian body and implants the half-breed Boddo.

The Boddo figure demonstrates how Whitman writes upon the Indian like a palimpsest: "his face was the index to many bad passions ... a malignant peevishness, dwelling on every feature" (EPF 258). In so doing, Whitman gestures toward disembodiment, emptying the Indian figure of corporeality and signaling the relation of the Indian to the process of writing. Additionally, the Catholic monk recounts his "intercourse" with an "Indian girl" during his first trip west:

"There was a young maiden of the tribe of - Bah! Why does the tell-tale colour rush up into my face, and mantle it with the hue of shame!

"... She loved me- and I-I had nothing to interrupt the tedium of our long stay. We were both with the hot blood of young veins. At the coming of the spring, I left the place.

"Some four or five seasons afterward, I came hither again. They showed the child of the Indian girl - my son! - I almost shrieked with horror at the monstrous abortion! . . . Never had my eyes been blasted with so much ugliness as that hunchback boy!" (EPF 272)

Hardly the writing of sexual transgression, the affair with an Indian girl strikes the eyes with "horror" and subsequently drives the man to celibacy. The scene thus speaks precisely to the idea of sexual merger; however, the terror of the priest far from validates miscegenation, and instead highlights the stain of redness as the priest recoils both from his biracial son and "the hue of shame" that "mantle[s]" his face simply at remembering the contact.

The dilation in time that "interrupts" the delivery of the priest's story is also important, for it emblematizes the act of writing or signifying indigenous identity. That is, Whitman substitutes punctuation or text for the name of the tribe here, a replacement that works to avoid and write over (ab)originality. Something similar occurs during Boddo's arrival in the story and merits quotation in full:

"But Bill!" said a larger and more sedate looking youth, addressing the elf, "Bill! be quiet, and don't act so foolish. Can't you see Mr. Caleb is looking at you?"

"Well," rejoined the other, "What if he-?"

The sentence which the exuberant child was about to utter was cut short suddenly, by a loud shout from seven or eight of his companions.

"Boddo! Boddo!" they cried, "Boddo is coming!" And they pointed with their mischievous fingers, to a turn in the road, at about ten rods distance, where a figure was seen slowly walking, or rather limping, towards them.

More than half the party started off on a gallop, and in a few moments they were at the side of him who had attracted their attention. Boddo, as the youngsters called himand that was the name he went by all over the settlement-appeared to be a man of about seven-and-twenty years of age. (EPF 258) 
Boddo's arrival is staged here by a series of interrupted sequences. First, an unnamed student advises another, Bill, to end his misbehavior, for the teacher is observing them. This signal to delay and discontinue, a precautionary measure against being seen, anticipates the second pause of the sequence. In this instance, the ambiguity of "the other"-is it Bill or the student who advises Bill? - aligns with the momentary sense of confusion at the point of interruption in the student's response. The punctuating line or long dash that signifies the broken sentence mirrors the action causing the disturbance. Just as the priest pauses when naming the tribe, presumably of "red men" (the epithet most used during the story) but marked superficially by text, the phrase most likely to follow in place of the interrupting break during Boddo's entry - "what if he [sees you]?"-recreates the event taking place, that of Boddo being seen by the children.

Conflating voice and vision here marks, then, another instance of Indian textualization, an inseparability of the figure from the inscriptions which assign it identity. Yet the moment also represents a collapse in the symbolic order structuring the text and the brief intrusion of an imaginary mode of identification. The moment communicates not by words but by an absence or gap in the language of the text. Thus, while the break works to alert the reader that something is coming, the objectcause of the interruption never quite crystallizes in sight. Even following the cut, we must trace the fingers of the children to see the figure approaching at a distance.

After Boddo arrives, a sense of imprecision regarding both his name and "appear[ance]" lingers: "the gazer would have been at some doubt whether to class this strange and hideous creature" (EPF 258). I have argued that the poet indeed labors to "class[ify]" Indian identity, to make the Indian figure readable and self-evident as such. The "doubt," here, not only dehumanizes the Boddo character but also registers a blindspot in the authority of the narrator. Slavoj Žižek notes that "the gaze . . . is a stain preventing me from looking at the picture from a safe, 'objective' distance, from enframing it as something that is at my grasping view's disposal." 19 Thus, the gaze that figures Boddo speaks of the narrator's desire to represent the Indian; yet, the very elusiveness of this gaze-the sense that something remains out of sight-points to a disturbing lack of aboriginal corporeality (perhaps even, humanity) in Whitman's text.

The assignment of Boddo's identity no doubt operates to contest the movement towards merger Sánchez-Eppler finds in miscegenation. At the same time, however, Boddo troubles the security with which Whitman delimits Indian identity. As a result, the initial description of Boddo also functions to de-scribe and undo Indian identity, making clear that its assignment depends on a discursive network that lacks 
positive or self presence. ${ }^{20}$ Whitman posits almost pictographic images of Indians in other, more poetic texts, sights that act to bind Indian bodies. Yet, like the figure of Boddo, these images also carry the implicit possibilities for disenabling the violent "manifest manners" of Indian identity construction.

\section{Indian In-Sight}

Vizenor links "manifest manners" to surveillance and theatricality, and thus his language helps to elucidate Whitman's ekphrastic representation of the Indian: "Manifest manners are the simulations of dominance; the notions and misnomers that are read as the authentic and sustained as representations of Native American Indians . . . The once bankable simulations of the savage as an impediment to developmental civilization, the simulations that audiences would consume in Western literature ... protracted the extermination of tribal cultures" (MM 56 ). The poet represents the Indian body with visual indicators that mistake a scene of recognition for an act of literary construction. More simply put, Whitman posits his own textual images as figures of indigenous authenticity. The figure is consequently cut with ambivalent and paradoxical inscriptions, revealing more about the nature of the dominant culture than unveiling, with any accuracy, a conception of Native America.

Vizenor underscores the Indian's symbolic construction, emphasizing the way in which the figure reflects a lack in (white) America's own sense of subjectivity: "The indian is a simulation, the absence of natives . . the other in a vast mirror of moods" (FP 15, 37). Notions of lack and otherness, along with the function of the gaze, form the crux of Whitman's 1860 poem, "Facing West From California's Shores." Although not explicitly concerned with the Indian figure, the poem (especially in its final version from 1867) resonates with a certain self-reflexive emptiness that helps to explain moments when the Indian appears in other poems:

Facing west from California's shores,

Inquiring, tireless, seeking what is yet unfound,

I, a child, very old, over waves, towards a house of maternity, the land of migrations,

look afar,

Look off the shores of my Western sea, the circle almost circled;

For starting westward from Hindustan, from the vales of Kashmere,

From Asia, from the north, from the God, the sage, and the hero,

From the south, from the flowery peninsulas and the spice islands,

Long having wander'd since, round the earth having wander'd,

Now I face home again, very pleas'd and joyous,

(But where is what I started for so long ago?

And why is it yet unfound?) ( $L G 110-111$ ) 
Speaking in the possessive as and for the national body, the poet here is aligned with the shores on which he stands. His "inquiring" gaze travels the globe in search of an oppositional figure against which he may project and form a self-definition. An alienation from the "house of maternity"a lack I read in terms of an original or coherent American identitycomes to motivate the poet's figural look, attempting to fetishize and (mis)recognize the other in order to identify himself. ${ }^{21}$

A similar moment occurs in a different poem published in 1860 , "A Hand-Mirror." The first line reads: "Hold it up sternly-see this it sends back, (who is it? is it you?)" (LG 268). Again, Whitman's mirror exudes a sense of ambivalent specularity, resembling the function of the gaze in "The Half-Breed." In "Osceola," a poem published in 1890 toward the end of Whitman's life, the poet redeploys both the mirror and the gaze explicitly in order to fashion the Indian. "Osceola" concerns the death of a Seminole resistance leader, captured in 1837 under an agreement of truce and imprisoned at Fort Moultrie in South Carolina. The poem was inspired, in part, by a George Catlin lithograph that hung in Whitman's Camden apartment:

When his hour for death had come,

He slowly rais'd himself from the bed on the floor,

Drew on his war-dress, shirt, leggings, and girdled the belt around his waist,

Call'd for vermilion paint (his looking-glass was held before him,)

Painted half his face and neck, his wrists, and back hands.

Fix'd his look on wife and little children-the last: . . ( $L G 550-551)$

Folsom writes that "a sense of honor betrayed and a quiet gesture toward righting the wrong" of colonization are evoked in the poem (77). Conversely, Maurice Kenny points to the preservation and display of the resistance leader's decapitated head in order to suggest that the poem "supports the fact that Whitman was either a blind Rousseauian romanticist, not well up on current events, or was an outright racist." 22

Both interpretations, however, ignore the figural mode employed to capture Osceola, namely the conspicuous "looking glass" just before the poem's middle line. The mirror aids the Osceola character in his preparations for death and works to structure the representation of "Osceola" the poem. That is to say, both the figures of the Indian and the poet make use of the mirror here for the purpose of construction and expression. Moreover, the parenthetical that locks in the mirror's mechanism parallels the poem's closing inscription, "(And here a line in memory of his name and death)" (LG 551). Blazoning Osceola's body with distinctive and differential markings, Whitman employs the looking glass to naturalize Indian identity; however, the mirror also reflects the work of the poet in "[drawing] on his war-dress" and "paint[ing] 
half his face and neck." In other words, just as a point of punctuation signals the narrator's presence while simultaneously effacing Whitman's authority in "The Half-Breed," the "looking glass" both marks and surrenders the poet's labor in "Osceola."

Thus, despite the differential markings which inscribe Osceola's identity, the poem depends on this reflexive surface to operate or read legibly. Confusing the act of constructing Osceola's representation for the positive presence of the Indian, a visual mode of figuration helps to solidify the signifying system on which the poet relies for meaning. In "Our Old Feuillage," the ekphrastic Indian scene reveals another gap in the poet's articulation of aboriginal America, explicitly avoiding a gesture of embodiment:

In arriere the peace talk with the Iroquois the aborigines, the calumet, the pipe of goodwill, arbitration, and indorsement,

The sachem blowing the smoke first toward the sun and then toward the earth, The drama of the scalp-dance enacted with painted faces and guttural exclamations, The setting out of the war-party, the long and stealthy march, The single file, the swinging hatchets, the surprise and slaughter of enemies. . . (LG 174)

The desire of the poet to celebrate the "American Soul" or "one Love, one Dilation or Pride" engenders an attempt at representing or including the Indian in a series of snapshots of the nation. The effort ironically achieves the opposite effect. Offering not a visceral place in his poetic construct, the poet of the body works both to exteriorize and spectralize the Indians in this scene. With the "smoke" from the pipe of the "sachem," the Indians here evoke ghostliness and fright, perhaps fittingly for a poem said to "sing the song of These, my ever-united lands-my body no more inevitably united, part to part, and made out of a thousand diverse contributions one identity, any more than my lands are inevitably united and made ONE IDENTITY" ( $L G$ 176). As Renée Bergland proclaims, "American nationalism must be predicated on haunted grounds: the land is haunted because it is stolen." 23

Indeed, the "pipe of good-will, arbitration, and indorsement" perhaps alludes to the origin of the nation, recognizing a Native presence and precedence. Yet, the terms "arbitration" and "indorsement" belie the poet's conception of equal participation, rewriting the violence on which the nation was founded. By an almost organic revision, leaving out any mention of violence, Whitman's attachment to the Indian again resurfaces only as text. In "Yonnondio," Whitman finds only an Indian word to celebrate:

A song, a poem of itself-the word itself a dirge,

Amid the wilds, the rocks, the storm and wintry night,

To me such misty, strange tableaux the syllables calling up. . . ( $L G 524)$ 
Folsom emphasizes Whitman's interest in Native American words, suggesting that "part of Whitman's campaign was to realign the English tongue, tune it American, by absorbing the Indian nomenclature, the native names for this land." ${ }^{24}$ However, by focusing on words alone, Whitman enacts a measure of somatic erasure, "I see swarms of stalwart chieftains, medicine-men, and warriors, / As flitting by like clouds of ghosts, they pass and are gone in the twilight" ( $L G 524)$. The language, here, resembles not absorption but cultural appropriation, a textualized gesture more akin to assimilationist politics.

In a similar manner, Whitman not only appropriates an Algonquian term for his 1860 title, "Starting from Paumanok," but, again, comes to reinsure the disappearance of Native people by pushing the Indian into a distant past: "Still the present I raise aloft, still the future of the States I harbinge glad and sublime, / And for the past I pronounce what the air holds of the red aborigines." Evoking a social-Darwinian logic of progress - "A new race dominating previous ones and grander far" ( $L G$ 26,27 ) - the poem thus both implies and confirms the terms of colonization:

The red aborigines,

Leaving natural breaths, sounds of rain and winds, calls as of birds and animals in the woods, syllabled to us for names,

Leaving such to the States they melt, they depart, charging the water and the land with names. ( $L G 26)$

Mobilizing the absence of the Indian with his speech act, the poet, however, distributes Indian signifiers across the natural landscape. In so doing, the differential identity with which Whitman circumscribes the Indian momentarily dissolves. The poem also recalls the final scene in "The Half-Breed." As Arrow-Tip awaits the time of his execution, he remarks to Deer, "'O, brother, the Great Spirit has frowned upon our race. We melt away, like the snows in spring."' Arrow-Tip continues, "Death is but a puff of air . . . and in the distance like the Green Hunting Grounds of the honest Indian" (EPF 287; italics mine). That Whitman alters little in his representation of the Indian, despite the fifteen years that separates the publication dates of "The Half-Breed" and "Starting From Paumonok," indicates, at best, a minimal commitment to developing an imaginative Indian figure.

Moreover, Whitman's fascination with Indian exteriors and mortality troubles his insistence that "a great poem is no finish to a man or woman but rather a beginning." 25 While the word "finish" suggests an end or finale, the term might also signify, as the OED notes, the outermost layer printed or painted "upon a surface." The latter connotation notably recalls the manner in which Whitman relates the Indian party from his 1865 journal to sculpture and portraiture ("Any first-class art- 
ist or sculptor would never tire of their powerful and massive forms"). Indeed, it often seems all Whitman can provide for the Indian is a certain type of "finish." Whitman's stress on poetic "beginnings," however, characterizes the one moment, I argue, which works to value the corporeality of the Indian.

\section{Waking Up "The Sleepers"}

Like Whitman's beliefs about great poetry, Meredith Anne Skura's comments on the work of figuration in dreams emphasize a language of origins and beginnings: "It is true that the dreamer has access to a primitive, nonmimetic mode of representation; this is what makes even the most mundane dream surface so different from life. ... In some instances, it indicates that the dreamer has actually gone back to a primitive way of seeing and representing the world, to a time when feelings were part of the landscape ... a mode of thinking in which wish, fear, and other subjective, emotionally tinged views have not been distinguished from reality." 26 Whitman's 1855 poem, now titled "The Sleepers," plunges the poet into a dreamscape resembling that which Skura describes. Standing out from other Whitman texts as the result of its resistance to "mimetic" or superficial representation, "The Sleepers" best dramatizes the ambivalence with which Whitman traces the Indian figure. In doing so, the poem not only speaks to a more intimate and perhaps less entrapping Indian representation, but in its national scope, "The Sleepers" helps to externalize the fantasy of a coherent national identity.

In "The Sleepers," Whitman works not to represent the dream state but to enact it and act in it: "I dream in my dream all the dreams of the other dreamers, / And I become the other dreamers. / I am a dance . . . . Play up there! the fit is whirling me fast" (LGVar. 110). The poet moves here to inhabit the psychic position of the other sleepers, entering their dream spaces in order to, as he puts it, "average" them: "one is no better than the other, / The night and sleep have likened them and restored them" (LGVar. 118). While at once this project appears somewhat intrusive, a violating survey of the unconscious that perhaps glosses over a social reality in which inequality persists, Whitman's insistence that "the diverse shall be no less diverse" looks through, rather than around, as the case in other writings, notions of disproportion or political inconsistency.

In other words, the poem takes as its thematic core the very act of constructing a national fantasy, one that blurs asymmetrical power and resource distribution as well as the traumatic self-recognition of occupying a place in the unequal American social and symbolic orders. Put differently, "The Sleepers," as the collection of dreams itself, realizes 
the phantasmatic labor at play in nationhood, and thus the poem destabilizes the typological certainty with which Whitman represents national figures at other moments. The piece, then, does not enable the poet, as Philip Fisher proclaims, to "abstract from [the sleepers] so as to reach that one point from which they can be imagined to be, at last, equally beautiful." ${ }^{27}$ Rather, the poem indicates precisely the manner in which Whitman's channeling or embodiment of the nation in other texts constitutes a mode of abstraction: an imaginary and synecdochic misrecognition that (mis)takes symbolic parts for the whole.

As a result, Whitman's depiction of night and darkness in "The Sleepers," instead of bleaching out all differences as Fisher suggests, reflects in its anxious tone and stories of separation, just how the poet's troubling markers of superficial identity presuppose a certain amount of ambivalence regarding textualization and corporeality. "I wander all night in my vision," the poet writes, "Wandering and confused . . . . lost to myself . . . . ill-assorted . . . . contradictory." Complicating his own interpretive lens, Whitman initially fails to draw meaning from what he sees. Babies transmogrify and become "ennuyees, the white features of corpses, the livid faces of drunkards, the sick-gray faces of onanists." The list continues, cataloguing soldiers, the clinically insane, and "sacred idiots" in the poet's scopic field (LGVar. 109). Even as Whitman bridges the gaps between these figures by grouping them together in a stanza, each image appears to stand descriptively apart from the rest.

Although the gender-bending phrase, "the night pervades them and enfolds them," perhaps intimates solidarity only as the result of darkness, the line also functions to expose the very blanket or poetic "finish" that prevents a sense of corporeality from infusing Whitman's textual representations of the Indian. ${ }^{28}$ By cloaking the figures in darkness and under the cover of sleep, the poet makes explicit the illusory dimensions of social reality and, rather than cancel out difference, works to expose the conceit of sameness.

Notions of difference indeed inflect the interaction of the poet's mother and the "red squaw." At the same time, the topos of difference conveys a sense of discursive intercourse-unlike a merger in which two bodies disappear into one-a movement in which duality itself becomes the empowering imaginary force:

A red squaw came one breakfasttime to the old homestead,

On her back she carried a bundle of rushes for rushbottoming chairs;

Her hair straight shiny coarse black and profuse halfenveloped her face,

Her step was free and elastic . . . . her voice sounded exquisitely as she spoke.

My mother looked in delight and amazement at the stranger,

She looked at the beauty of her tallborne face and full and pliant limbs,

The more she looked upon her she loved her,

Never before had she seen such wonderful beauty and purity; 
She made her sit on a bench by the jamb of the fireplace .... she cooked food for her,

She had no work to give her but she gave her remembrance and fondness.

(LGVar. 115-116)

In the first part of the scene, the poet's mode of figuration is somewhat typical; the "back" of the Indian woman literally bears the signs of her identity and purpose. In contrast to the confined "red girl" in "Song of Myself," however, the female Indian in "The Sleepers" appears dynamic and mature. Michael Moon rightly observes an elusive imprecision regarding the pronouns in the second part of this scene (85). At moments it appears unclear to whom the "she" refers; yet the engagement, or inter-attraction, of the two women fails to waver, approaching an erotic sense of bodily entanglement.

As the two women explore the hybridizing territory of cultural crossing, the scene resembles the work of the nineteenth-century American author perhaps most notorious for depictions of Indian-white encounters. The meeting of the Indian woman and the poet's mother closely approximates the relationship of Hetty and Hist in James Fenimore Cooper's 1841 novel, The Deerslayer. While many parallels might be drawn to support this connection, I am most interested in the discourse surrounding the proposition of friendship between Hetty and Hist. ${ }^{29}$

After the two meet in the woods near Lake Glimmerglass, the young Indian woman, Hist, leads the devoutly religious, though "feebleminded" Hetty into a secluded area by the lake's shores. Cooper not only works to emphasize their privacy and isolation, away from any "probable observers," but also stresses the physical attraction the two women share. After a brief but engaged dialogue about their relationships to men-fathers and fiancés-Hist makes explicit the budding friendship between the two women and elicits Hetty's response:

'I never had a friend,' answered Hetty, returning the warm embrace with unfeigned earnestness; 'I've a sister, but no friend. Judith loves me, and I love Judith; but that's natural, and as we are taught in the Bible; but I should like to have a friend! I'll be your friend, will all my heart; for I like your voice, and your smile, and your way of thinking. . . . ${ }^{30}$

Saturating the language of friendship with sexual connotation, Cooper's passage helps to enhance our reading of Whitman's poem. The language here contrasts Hetty's love of Hist not simply to that of her sister, Judith, but to Hetty's affiliation with the Bible. In so doing, Cooper's construction of their relationship works to transgress the boundaries of text. Although Hetty suggests befriending an Indian woman signifies something unnatural, it seems also to signify something that eludes textual representation. 
While we cannot be sure that Whitman read (or did not read) The Deerslayer, the interaction of the two women in Cooper's novel did, in fact, inspire at least one artist to recreate the scene. In Tompkins H. Matteson's 1857 painting, The Meeting of Hetty and Hist, both characters appear lost in the exchange of an affective gaze (see Figure 1). ${ }^{31}$ The text in Hetty's left hand perhaps represents the Bible, yet the nondescript cover offers nothing definitive. (The book might also represent The Deerslayer or, even, the first edition of Leaves of Grass.) Moreover, the sloping angle of the women's shoulders and the ebbing pull of the lake's tide fur-

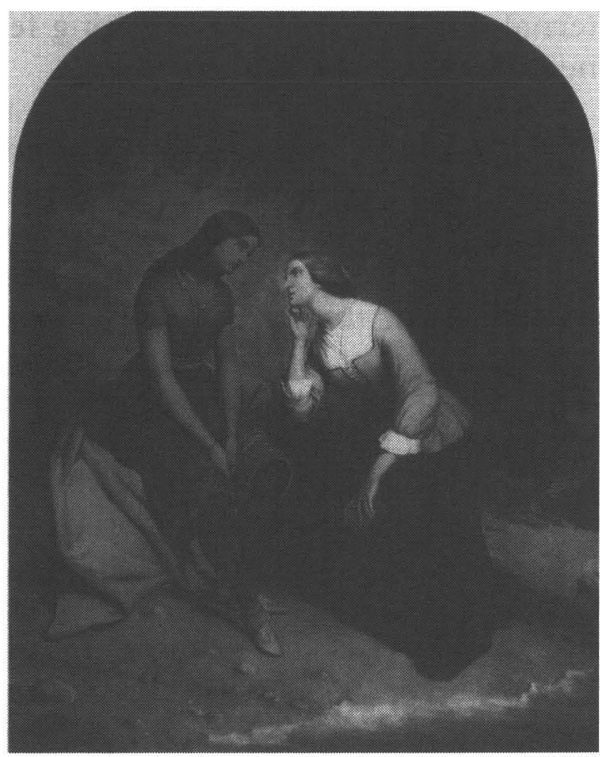

Figure 1. Tompkins H. Matteson, The Meeting of Hetty and Hist (1857). ther enhances the image of the book. Indeed, Hetty appears not only uninterested in the text but ready to dispose of it, as her eyes meet Hist's in a romantic and suggestive ocular embrace.

That the book in Matteson's painting lacks character helps to reinforce the mediation in textual representations of the Indian. Just as Hetty's hand seems positioned to discard the text in the painting, Whitman's "squaw" figure in "The Sleepers" is poised to slip away from Leaves of Grass:

The red squaw staid all the forenoon, and toward the middle of the afternoon she went away;

O my mother was loth to have her go away,

All the week she thought of her . ... she watched for her many a month,

She remembered her many a winter and many a summer,

But the red squaw never came nor was heard of there again. (LGVar. 116)

Like the dissolution of her ascribed identity in moments of corporeal contact, the departure of the Indian woman indicates the poet's resistance in "The Sleepers" to the confining terms of representation. In addition, the vignette's layering of temporality evokes a sense of indeterminacy. The story is simultaneously the poet's and his mother's memory of the encounter with an Indian woman. As a result, while the "squaw" figure in "The Sleepers" no doubt resonates as a national icon, an emblem not that unlike the symbolic Indian Whitman represents elsewhere, the scene also points to the inevitable separation from a ma- 
ternal presence and the resulting feelings of discontinuity and disconnection.

Whereas Whitman re-presses the indigenous body in other writings, enabling his own body to stand in for the fantasy of national unity, "The Sleepers" makes clear the terms of this engagement. That is, Whitman's attempt to imagine national harmony requires not only the symbolic and silent inclusion of the Indian figure, but also a coherent projection of the poet's own image, a self-identity that indeed stands "apart from the pulling and hauling" of national culture (LGVar. 5). The disappearance of the Indian woman, in some sense then, signals the internal inconsistencies and divisions of both the poet and the nation.

The poem thus alludes to the politics of Indian removal and the poetics of Indian figuration. Representing the Indian in the nineteenth century, in terms of politics or poetics, calls into question that very act of representation. The presence of the Indian-an "aboriginal-outsider"-in the American state exposes the contradictory operations of national construction, destabilizing the mythic foundation on which the nation resides. Returning briefly to Skura, "only in moments of . . . disorientation and sleepiness do we regress into a state in which we are unsure of the rules again" (127). Expressing the desire for a maternal and aboriginal embrace that "America" seems to lack, Whitman's disorientation in "The Sleepers" disrupts the putative rules of an illusory (nation) state. The poem, then, is not about sleeping but a wakeup call, an alarm that sounds the discord of the poet's imaginary nation. It is a poem, in other words, that allows us to read in Whitman's dreams what makes his politics of the body both so visionary and so contestatory.

\section{Cornell University}

\section{NOTES}

For insightful and inspiring comments on earlier drafts of this essay I thank Betsy Erkkila and Jules Law, as well as the editors and anonymous readers of $W W Q R$.

1 In my essay, I reserve the word "Indian" to mark a Euro-American construction, while the word "Native" is deployed in opposition to such static and museumized identity configurations. This methodology is derived from Gerald Vizenor: "The indian is a simulation and loan word of dominance . . . the indian has no native ancestors; the original crease of that simulation is Columbian." See Fugitive Poses: Native American Indian Scenes of Absence and Presence (Lincoln: University of Nebraska Press, 1998), 14-15. Hereafter FP. In other words, the "Indian" points to a colonial fabrication, a figuration, and a fantasy of otherness that locates its referent in a Euro-American attempt to construct artificial limitations in an ongoing narrative of discovery.

2 Leaves of Grass: A Textual Variorum of the Printed Poems, ed. Sculley Bradley, Harold Blodgett, Arthur Golden, William White (New York: New York University Press, 1980), 1:61. Hereafter LGVar. 
3 Though the term "red marauder" is ambiguous and worthy of critical attention in itself, I am led to read it as a reference to Indians given Whitman's extensive use of "red" as an epithet for Native Americans.

4 Karen Sánchez-Eppler, Touching Liberty: Abolition, Feminism, and the Politics of the Body (Berkeley: University of California Press, 1993), 10.

5 Michael Moon, Disseminating Whitman: Revision and Corporeality in Leaves of Grass (Cambridge: Harvard University Press, 1991), 6.

6 Ed Folsom, Walt Whitman's Native Representation (New York: Cambridge University Press, 1994), 65. I differ from Folsom in that I hope to emphasize the instability and inconsistency of the American "character," or national figuration, rather than the place or "role" of the Native within it.

7 Leaves of Grass, Comprehensive Reader's Edition, ed. Harold W. Blodgett and Sculley Bradley (New York: New York University Press, 1965), 711. Hereafter LG.

8 Jimmie Durham, "Cowboys and .. . Notes on Art, Literature, and American Indians in the Modern American Mind," The State of Native America: Genocide, Colonization, and Resistance, ed. M. Annette Jaimes (Boston: South End Press, 1992), 425.

9 Sánchez-Eppler 52. I mean to suggest, here, a wholly conventional method of representation, whereby the poet works to eschew the ambiguity of the imaginary-or the "complete undifferentiated oneness" Sánchez-Eppler observes-in favor of the social certainty the symbolic order offers. See Kaja Silverman, The Subject of Semiotics (New York: Oxford University Press, 1983), 178-193, for an account of the Lacanian symbolic order to which I refer.

10 Notebooks and Unpublished Prose Manuscripts, ed. Edward F. Grier (New York: New York University Press, 1984), 2:880-881. Hereafter NUPM.

11 Eric Cheyfitz, The Poetics of Imperialism: Translation and Colonization from The Tempest to Tarzan (Philadelphia: University of Pennsylvania Press, 1997), xii.

12 Homi K. Bhaba, The Location of Culture (London and New York: Routledge, 1994), 86.

13 Gerald Vizenor, Manifest Manners: Postindian Warriors of Survivance (Hanover, NH: Wesleyan University Press, 1994), 9. Hereafter $M M$.

14 M. Jimmie Killingsworth, Whitman's Poetry of the Body: Sexuality, Politics, and the Text (Chapel Hill: University of North Carolina Press, 1989), 3.

15 Betsy Erkkila, "Whitman and American Empire," in Geoffrey M. Sill, ed., Walt Whitman of Mickle Street (Knoxville: University of Tennessee Press, 1994), 63.

16 Moreover, by evoking the association of the Indian woman with the image of America, we might read the "squaw" as selling not simply "moccasins and beadbags" but the right to the nation's land. For observations on the connection between images of the Indian woman and national identity, see Berkhofer and Cheryl Walker, Indian Nation: Native American Literature and Nineteenth-Century Nationalisms (Durham: Duke University Press, 1997).

17 The Early Poems and the Fiction, ed. Thomas L. Brasher (New York: New York University Press, 1963), 257. Hereafter EPF.

18 Philip Deloria, Playing Indian (New Haven: Yale University Press, 1998), 58. Also see Shari Huhndorf, Going Native: Indians in the American Cultural Imagination (Ithaca: 
Cornell University Press, 2001), 1-78, for a discussion of the Indian in the (white) American cultural imaginary.

19 Slavoj Žižek, Looking Awry: An Introduction to facques Lacan Through Popular Culture (Cambridge: M.I.T. Press, 1991), 125.

$20 \mathrm{I}$ am, in part, referring to the Derridian notion of citationality. Whitman constructs Boddo in terms of difference, and thus the momentary ambiguity in Boddo's identity implicitly destabilizes the potential for discrete identities in general. See Derrida, "Ellipsis," Writing and Difference, trans. Alan Bass (Chicago: University of Chicago Press, 1978), 294-300.

21 See Scheckel: "Just as the construction of the self-image during the mirror stage as something unified and controllable to some extend depends on a denial of reality, so the construction of the nation as a homogenous union of citizens also depends on an essential denial of reality" (12).

22 Maurice Kenny, "Whitman's Indifference to Indians," Greenfield Review 14 (Summer/Fall 1987), 105.

23 Renée Bergland, The National Uncanny: Indian Ghosts and American Subjects (Hanover, NH: Dartmouth College University Press of New England, 2000), 9.

24 Folsom 81, See Folsom (80-88) for a survey of Whitman's remarks on the languages and names of various tribes.

25 I cite from the "Preface" to the 1855 edition ( $L G 727$ ).

26 Meredith Anne Skura, "Literature as Dream: Mode of Representation," Sigmund Freud's The Interpretation of Dreams, ed. Harold Bloom (New York: Chelsea House, 1987), 125.

27 Philip Fisher, "Democratic Social Space: Whitman, Melville, and the Promise of American Transparency," Representations 24 (Fall 1988), 72.

28 LGVar. 109, my emphasis. Žižek explains, "there is a gap that forever separates the fantasmatic kernel of the subject's being from the more 'superficial' modes of his or her symbolic and/or imaginary identifications." See Žižek, "Love Thy Neighbor? No, Thanks!," The Psychoanalysis of Race, ed. Christopher Lane (New York: Columbia University Press, 1998), 154-175. In other words, as the night connotes both masculine and feminine significations - a phallic sense of "pervad[ing]" and a maternal notion of "enfold[ing]" - the symbolic order that assigns social roles and governs representation collapses. The night, then, serves to mark "the fantasmatic kernel of the subject's being," the Lacanian "real" that eschews symbolic representation.

29 We might, for instance, point to the regional similarity between the novel's setting and the area in which Whitman's mother lived as a child. Also notable is the extended description of Hetty's sleep in the woods prior to meeting Hist. I am not attempting to explain why Whitman included the scene of his mother and the Indian woman in a poem about sleeping and dreaming; rather, I wish to explore and enrich the cultural significance of the scene.

30 James Fenimore Cooper, The Deerslayer (New York: Bantam Books, 1982), 154.

31 Tompkins H. Matteson, The Meeting of Hetty and Hist, reprinted in The West as America: Reinterpreting Images of the Frontier, 1820-1920, ed. William Truettner (Washington: Smithsonian Institution Press 1991), 147. 